\title{
17. 'Nesne' olmaktan ‘özne' olmaya: Elizabeth Barrett Browning ve Christina Rossetti’nin sonelerinde Petrarca sone geleneğinin kadın bakış açısıyla yeniden yazımı
}

Seçil VARAL ${ }^{1}$

APA: Varal, S. (2021) 'Nesne' olmaktan 'özne' olmaya: Elizabeth Barrett Browning ve Christina Rossetti'nin sonelerinde Petrarca sone geleneğinin kadın bakış açısıyla yeniden yazımı. RumeliDE Dil ve Edebiyat Araştırmaları Dergisi, (Ö9), 193-203. DOI: 10.29000/rumelide.981532.

$\ddot{0} \mathbf{z}$

Viktorya Dönemi İngiltere'de toplumsal cinsiyet rollerinin en baskın olduğu dönemlerin başında gelir. Katı ahlak kurallarının egemen olduğu bu dönemde, kadın toplum tarafından belirlenmiş basmakalıp rollere sıkıştırılmıştır. Öyle ki, kendini ailesine adamış iyi bir eş, anne ve ev hanımı olması beklenen kadın yalnızca duygularıyla var olurken akıl, mantık ve entelektüellik yalnızca erkeklere atfedilen özelliklerdir. Dolayısıyla, şair olmak kadınların yapabileceği bir iş değildir, kadınlar ancak şiirin 'nesne'si olabilir çünkü ataerkil toplumda erkekten her açıdan aşağı görülen kadın, erkeğe karşı yalnızca güzelliği ile üstünlük sağlayabilir. Bu bağlamda, "saray aşkı" geleneği çerçevesinde âşık olduğu kadının güzelliğini, sadakatini, erdemini, ahlakını yücelten, mükemmelliğini idealize eden bir aşı̆̆ın saplantılı ama karşılıksız aşkını konu edinen Petrarca'nın sone geleneği, yalnızca erkeklere atfedilen ve kadını arzu edilen bir nesne olarak ele alan en bilinen şiir türlerinden biridir. Bu çalışma, Viktorya Dönemi İngilteresi'nin önde gelen iki kadın sone yazarı Elizabeth Barrett Browning ve Christina Rossetti'nin "Sonnets from the Portuguese" ve "Monna Innominata" adlı sone dizilerinde erkek egemen Petrarca sone geleneğinin kadın bakış açısıyla yeniden yazılmasını ele almaktadır. Bu çerçevede, çalışma Browning ve Rossetti'nin yazdıkları soneler ile kadınları şiire yalnızca güzellikleriyle ilham veren birer 'nesne' olmaktan çlkarıp, şiirin hisseden ve düşünen "öznesi” yaparak hem toplumda hem de edebi eserlerde nesneleștirilen, edilgenleștirilen ve sessiz kılınan kadınların sesi olduklarını ileri sürmektedir.

Anahtar kelimeler: Petrarca sone geleneği, Elizabeth Barrett Browning, Christina Rossetti, "Sonnets from the Portuguese", "Monna Innominata"

\section{From being 'object' to being 'subject': the rewriting of Petrarch's sonnet tradition from a female perspective in the sonnets of Elizabeth Barrett Browning and Christina Rossetti}

\begin{abstract}
The Victorian Age is one of the primary periods predominated by gender roles in England. In this period of strict moral rules, women are confined to stereotypical roles determined by society. That is, a woman, who is expected to be a good wife, mother and housewife devoted to her family, exists only with her emotions, while reason, logic and intellectuality are the characteristics attributed only to men. In this sense, being a poet is not a women's occupation, women can only be the 'object' of poetry because they are regarded as inferior to men in every respect in patriarchal society, and they can gain superiority over men only with their beauty. In this context, dealing with the obsessive but unrequited love of a lover who idealizes the beauty, loyalty, virtue and morality of his beloved with a "courtly love tradition", the Petrarch sonnet tradition is one the most popular poetic genre, which is attributed only to men and regards women as objects of desire. This study elaborates on the rewriting of the male-dominated
\end{abstract}

Dr. Öğr. Üyesi, Karamanoğlu Mehmetbey Üniversitesi, Edebiyat Fakültesi, İngiliz Dili ve Edebiyatı Bölümü (Karaman, Türkiye). svaral@kmu.edu.tr. ORCID ID: 000000023776 769X. [Araştırma makalesi, Makale kayıt tarihi: 16.07.2021-kabul tarihi: 20.06.2021; DOI: 10.29000/rumelide.981532]

RumeliDE Dil ve Edebiyat Araştırmaları Dergisi Osmanağa Mahallesi, Mürver Çiçeği Sokak, No:14/8 Kadıköy - ISTANBUL / TÜRKIYE 34714 e-posta: editor@rumelide.com tel: +90 505 7958124, +90 2167730616
Address

RumeliDE Journal of Language and Literature Studies

Osmanağa Mahallesi, Mürver Çiçeği Sokak, No:14/8

Kadıköy - ISTANBUL / TURKEY 34714

e-mail: editor@rumelide.com

phone: +90 5057958124, +90 2167730616 
From being 'object' to being 'subject': the rewriting of Petrarch's sonnet tradition from a female perspective in the sonnets of Elizabeth Barrett Browning and Christina Rossetti / S. Varal (pp. 193-203)

Petrarch sonnet tradition from a female perspective in the sonnets sequence "Sonnets from the Portuguese" and "Monna Innominata" composed by two leading poetesses of Victorian England, Elizabeth Barrett Browning and Christina Rossetti. In this context, the study argues that in their sonnet sequences, Browning and Rossetti give voice to objectified, passivated and silenced women in society as well as in literary works by transforming them from 'objects' into the "subjects" who have feelings and thoughts.

Keywords: Petrarchan sonnet tradition, Elizabeth Barrett Browning, Christina Rossetti, "Sonnets from the Portuguese", "Monna Innominata”

\section{Giriş}

Kadın olduğunuz için,

Yalnızca kadın, özel ve tutkulu,

Bize fedakâr anneler ve mükemmel eşler verebilirsiniz ancak

Yüce Madonnalar ve çilekeş azizeler,

Sizden bir Mesih çıkmaz ve doğrusu

Düşünüyorum da bir şair de çlkmaz.

(Elizabeth Barrett Browning, Aurora Leigh, 28)

Elizabeth Barrett Browning'in temelde bir kadının şair olma yolcuğunu ele aldığı Aurora Leigh (1856) adlı manzum romanında Romney Leigh'in Aurora'ya söylediği bu sözler Viktorya Dönemi İngilteresi'nde kadına bakış açısını açıkça gözler önüne sermektedir. Viktorya Dönemi'nde kadın toplumda yalnızca toplumsal cinsiyetin onu hapsettiği fedakâr anne, mükemmel bir eş ve kendini ev işlerine adamış iyi bir ev hanımı rolleriyle var olmaktaydı. Dolayısıyla, çoğunlukla okuma yazma bilmeyen eğitimsiz kadının domestik sınırlar içerisinde kalıp çocukları ve ev işleriyle ilgilenmesi, bir azize kadar ahlaklı ve sadık olması beklenmekteydi. 'Evdeki melek' kalıbının dışına çıkamayan, erkekten her açıdan aşağı görülen kadın, bu yüzden edebiyat sahnesinde yazar olarak yer bulamamakta, ancak takma isimler kullanarak kendini gösterebilmekteydi.2 Dahası, kadının entelektüel bir birikim gerektiren şairlik mesleğini icra etmesi, Romney'in de dile getirdiği gibi, ataerkil Viktorya toplumunda pek mümkün görünmemekteydi. ${ }^{3}$

Özellikle, aşk temalı Petrarca sone geleneğinin öznesi olmak kadın için neredeyse imkansızdı. Öncelikle, Viktorya döneminin katı ahlak kuralları ve tutuculuğu göz önüne alındığında, bir "azize" kadar ahlaklı ve sadık olmakla yükümlü kılınan kadın için bir aşk sonesinin 'öznesi' olmak ahlaksızlık olarak nitelendirilmekteydi. İkincisi, eğer kadınlar kendilerini arzulayan birer özne olarak ifade etseler, Havva'nın günahını işlemek ile suçlanırlardı (Distiller, 2008: 30). Üçüncüsü ise, Sandra Gilbert ve Susan Gubar’ın “The Aesthetics of Renunciation" adlı çalışmalarında da dile getirdiği gibi kadınlardan beklenen özveri ve fedakârlık şiirdeki kendinden emin lirik 'ben' ile çelişmekteydi (1996: 129). Bu çerçevede, toplumsal

2 Viktorya Dönemi'nin önde gelen kadın yazarlarının çoğu toplumdaki cinsiyet ayrımcılığından ve kadınlara karşı olan ön yargıdan kurtulmak için ilk eserlerini takma isimlerle yayımlamışlardır. Örneğin, Mary Anne Evans ilk kitabını 'George Eliot' adı ile basar ve hala bu isimle anılır, Emily, Chartlotte ve Anne Bronte sırasıyla 'Ellis', 'Currer' ve 'Acton' Bell isimlerini kullanmışardır.

3 İngiltere'de kadından şair olmaz algısının oluşmasında toplumsal cinsiyet rollerinin yanı sıra kadın şairlere edebiyat sahnesinde yer verilmemesinin, dolayısıyla, geçmişten günümüze ulaşan kadın şair sayısının oldukça az olmasının da etkisi vardır. Bu durumu Elizabeth Barrett Browning șu sözlerle dile getirir: “İngiltere’de çok fazla bilge kadın var, Elizabeth dönemi ve sonrasında farklı dillerde sadece okuyan değil aynı zamanda yazan kadınlar- edebiyatta şimdi olduğundan derin kazanımları olan kadınlar fakat kadın șairler nerede? Bu topraklardan gelip geçen ve geçmeden buraları șimdi 'eski yazarlar' olarak çağırdığımız bir sürü şair ile dolduran kutsal nefes neden -lirik formda bile- kadınların dudaklarına geçmedi? Ne kadar enteresan! [...] büyükannelerimizi bulmak için her yere baktım ama hiçbirini göremedim" (aktaran Garrett, 2000; 17).

Adres Address

RumeliDE Dil ve Edebiyat Araştırmaları Dergisi $\quad$ RumeliDE Journal of Language and Literature Studies Osmanağa Mahallesi, Mürver Çiçeği Sokak, No:14/8 $\quad$ Osmanağa Mahallesi, Mürver Çiçeği Sokak, No:14/8

Kadıköy - İSTANBUL / TÜRKIYE 34714 Kadıköy - ISTANBUL / TURKEY 34714 e-posta: editor@rumelide.com e-mail: editor@rumelide.com, tel: +90 $5057958124,+90216773$ o 616 phone: +90 505 7958124, +90 216773 o 616 
cinsiyet rollerine hapsedilmiş öznellikten yoksun kadın, yoğun hislerle bezenmiş lirik şiirin gerektirdiği öznelliğe ters düşmekteydi.4 Nitekim, şair olması olanaksız görünen dolayısıyla şiirin arzulayan 'öznesi' olamayan kadın, yüzyıllardır süregelen Petrarca'nın sone geleneğinde şiire güzelliğiyle ilham kaynağı olarak şiirin arzu edilen 'nesnesi' haline gelmiştir.

İtalyan şair Francis Petrarca'nın 13. yy'da Laura'ya duyduğu aşkı yüceltmek için yazdığı otobiyografik sone dizileri, yalnızca güzelliğiyle ve erdemiyle var olan, sessizleştirilmiş kadın imgesinin somut bir örneğidir. Öyle ki, Petrarca Laura'nın adından, güzelliğinden ve evli olduğundan başka hakkında pek bilgi vermez, güzelliğini alakasız benzetmelerle överek sevdiğini kişiliği olmayan bir arzu nesnesine dönüștürür. Yanıt verme hakkından yoksun Laura'nın sonelerde hiç sesi duyulmaz. Öte yandan, Viktorya Dönemi'nin önde gelen iki kadın şairi Elizabeth Barrett Browning ve Christina Rossetti erkek egemen bu sone geleneğini kadın bakış açısıyla yeniden yazarak nesneleştirilmiş kadınlara yanıt verme hakkı sunarlar. Bu çalışma, Elizabeth Barrett Browning'in kaleme aldığı "Sonnets from the Portuguese" ve Christina Rossetti'nin "Monna Innominata" adlı sone dizilerinde kadınları aşk şiirlerinin arzulanan 'nesnesi'nde arzulayan 'öznesi'ne dönüştürerek Petrarca sone normlarını yıkmalarını gözler önüne sermeyi amaçlamaktadır. Bu bağlamda, çalışma, Browning ve Rossetti'nin yazdıkları aşk sone dizileriyle ${ }^{5}$ sadece güzellikleriyle şiire ilham kaynağı olan ve hem toplumda hem de edebi eserlerde nesneleștirilen, edilgenleștirilen ve sessiz kılınan kadınların sesi olduklarını ileri sürmektedir.

\section{Petrarca sone geleneği: arzu nesnesi olarak kadın}

İtalyanca "kısa şarkı" anlamına gelen "sonnetto" kelimesinden türeyen sonenin ortaya çıkması $1230^{\prime} \mathbf{l u}^{6}$ yllara dayansa da sone geleneğini geliştiren ve aşk sonesi söz konusu olduğunda şüphesiz akla ilk gelen isim İtalyan şair Francis Petrarca'dır (1304-74). Farklı çeşitleri olsa da 'oktav' (sekizli dize), 'sestet' (altılı dize) ve genellikle bu iki kısım arasında bulunan 'volta' yani 'dönüş' bölümlerinden meydana gelen on dört dizeden oluşan Petrarca sonesi, temelde evli bir kadına duyulan saplantılı aşkı ve bu aşkın nihayete erdirilememesinden dolayı karasevdalı aşığın çektiği acıyı ve gelgitlerini anlatır. Bu çerçevede, Petrarca'nın 13. yy'da Laura'ya duyduğu aşkı yüceltmek için yazdığı aşk soneleri yalnızca güzelliğiyle ve erdemiyle var olan, sessizleștirilmiş kadın imgesinin somut bir örneğidir.

Petrarca 1330'larda yazmaya başladığı 317'si sone olmak üzere toplam 366 şiirden oluşan ve Rime Sparse (Parçalar) olarak da bilinen otobiyografik sone dizisi Canzoniere ile Laura'ya duyduğu derin aşkı anlatır. Canzoniere'de, arzularını, üzüntülerini, çekincelerini ve içsel hesaplaşmalarını tüm öznelliğiyle ortaya koyan Petrarca aşk soneleriyle Shakespeare'den William Wordsworth'e, kendinden sonraki birçok şaire ilham olmuş böylelikle sone geleneğin temellerini atmıştır. "Desiring Voices Women Sonneteers and Petrarchism” adlı makalesinde, Mary Moore Petrarca sone geleneğinin özelliklerini şöyle özetler:

Tipik Petrarca sonelerinde âşık hem acıyı hem sevinci, yaşamı ve ölümü deneyimler, kızgın ve dingin, ağlamaklı ve neșelidir, özgür olsa da köledir; sevgilinin göz oklarından yaralanır, sureti onun kalbinde

$4 \quad$ "Substituting for Laura: Objects of Desire for Renaissance Women Poets" adlı çalışmasında Janet Levarie Smarr kadınların Petrarca aşk sonesi yazamamalarının nedenlerine bir yenisini ekler. Çalışmasında Rönesans dönemindeki İtalyan kadın şairleri ele alan Smarr’a göre, kadın şairler için Laura'nın yerine geçebilecek erkek bir arzu objesi bulmak oldukça zordur çünkü Laura için kullanılan benzetmeler, altın bukleler, yıldız gibi parlayan gözleri, güzel ayakları, erkek arzu objesine nasıl uyarlanabilir. Dahası "bir kadının teklifini iffeti yüzünden geri çeviren bir erkek asil değil ancak gülünç görünür” (2001: 2).

5 Sone geleneği çok eskilere dayansa da "sone dizisi" kavramı ilk defa 19.yy’da Gabriel Rossetti tarafından ortaya atılmıştır. Rossetti bu terimi “House of Life” (1870-1881) adlı eserindeki șiirleri nitelendirmek için kullanmıștır. Daha detaylı bilgi için bkz. Distiller, Natasha (2008). Desire and Gender in the Sonnet Tradition. London: Palgrave Macmillan, s.44.

6 Sone geleneğinin ortaya çıkışını ve gelişimini ele aldığı The Development of Sonnet An Introduction adlı kitabında, Michael R. G. Spiller sonenin ilk olarak 1230 'lu yıllarda güney İtalya'da ortaya çıktığını ve 13.yy'a kadar yaklaşı bin tane İtalyanca sone yazıldığını dolayısıyla Francis Petrarca 14.yy'ın ortalarında sone yazmaya bașladığında hali hazırda oldukça gelişmiş bir şiir enstrümanını miras aldığını belirtir (1992: 1).

RumeliDE Dil ve Edebiyat Araştrmaları Dergisi Osmanağa Mahallesi, Mürver Çiçeği Sokak, No:14/8 Kadıköy - İSTANBUL / TÜRKIYE 34714 e-posta: editor@rumelide.com tel: +90 505 7958124, +90 2167730616
Address

RumeliDE Journal of Language and Literature Studies

Osmanağa Mahallesi, Mürver Çiçeği Sokak, No:14/8

Kadıköy - ISTANBUL / TURKEY 34714

e-mail: editor@rumelide.com,

phone: +90 $5057958124,+902167730616$ 
From being 'object' to being 'subject': the rewriting of Petrarch's sonnet tradition from a female perspective in the sonnets of Elizabeth Barrett Browning and Christina Rossetti / S. Varal (pp. 193-203)

yer alır; o solgundur ve "hastalıklıdır düşüncenin soluk ıșığından"; gözleri yokluğu dünyayı karartan bir güneştir; gece sonsuzdur ya da çok çabuk biter; kalbi ve gözleri onun sureti için savaşır; altın sarısı saçları, mercan dudakları, kar rengi teni, gül gibi yanakları vardır. (1945; 7-8)

Diğer bir deyişle aşık, saray aşkı geleneğindeki gibi, aşkının karşılıksız olmasından dolayı acı çeker, fakat aynı zamanda böyle bir güzellikle karşılaştığı için kendini şanslı sayar ve sevinir de. Bu bağlamda, şiirin merkezinde aşık olunan kadından ziyade karasevdalı erkek ve onun yoğun hisleri vardır. Aşık, sevdiğinin güzelliğini olağandışı benzetmelerle yüceltir, dolayısıyla kadın güzelliğiyle şehvet uyandıran bir arzu nesnesine dönüşür, sessizleștirilir ve edilgenleştirilir. Ahlaki seçimleri ve iç dünyasından ziyade yalnızca vücudunun belli parçalarından ibaret olan kadın, bir bütünlükten yoksun "mercan dudakları", "altın sarısı saçları", gülüşü, bakışı ile belirir sonelerde çünkü aşık olunan kadının karakteri değil, fiziksel güzelliği, erdemli ve onurlu duruşudur.

Petrarca'nın aşk sonelerinde Laura'nın görsel bir nesne ve arzu nesnesi olduğu, değerli metalarla kıyaslanması (Sone 157'deki "altın saç", "kristal gözyaşı" gibi) (1996: 456) ve olanaksız benzetmelerle övülmesi ile üstü kapalı bir şekilde ima edilmesinin yanı sıra kullanılan sözcüklerle de açıkça ortaya konur. Petrarca Canzoniere'de 'Laura'dan bahsederken 'nesne' anlamina gelen İtalyanca "obietto"7 kelimesini kullanır (Knecht, 2011: 241). Örneğin, Petrarca gözlerinin Laura'dan bașka bir şey görmediğini Sone 226'da şu sözlerle dile getirir: "Çatıdaki hiçbir serçe, ya da ormandaki bir hayvan/ yalnız olabilir benim kadar çünkü göremiyorum/ güzel yüzünü ve ne ondan başka bir güneș tanıyorum/ ne de gözlerim ondan başka bir nesne arıyor" (1996: 579). Benzer bir şekilde, Laura'yı göremediğinden yakındığı Sone 257'de görüşünün 'nesne'sinden yoksun olduğunu söyler.

Petrarca'nın şiirlerinde Laura'yı sessiz bir arzu nesnesi olarak betimleyip kişiliğine hiç değinmemesi, Laura hakkında detaylı bilgi vermemesi onun gerçek bir kişilik mi yoksa hayali bir sevgili, idealize edilmiş kurmaca bir aşk mı olduğu konusunda tartışmalara yol açar. Petrarca'nın Laura ismini 'meltem', 'altın', 'defne' ve 'taç' anlamlarına gelen İtalyanca "l'aura, l'auro, lauro ve laurea" kelimeleriyle cinas yapması ve kelime oyunları kullanması 'Laura' isminin bilinçli olarak seçildiği varsayımlarının ortaya atılmasına neden olmuștur (Trapp, 2001: 66; Remoortel 2006: 252). Nitekim, Petrarca Virgil'in kitabının boş sayfasına eklediği notta Laura'yı ilk defa 6 Nisan 1327'de Avignon'da bulunan Saint Clare Kilisesi'nde gördügünü söyler. ${ }^{8} \mathrm{Bu}$, bir taraftan Laura'nın şiirsel bir kurmacadan ibaret olmadığını ortaya koyarken diğer taraftan da Laura ile kilise ayini sırasında karşılaşması karakteri hakkında pek de bir șey bilinmeyen Laura'nın erdeminin ve ahlakının övülmesini bir nebze olsun açıklar.

Yaşadığı süre zarfında idealize edilen güzelliğiyle, erdemli ve ahlaklı olmasıyla mükemmel bir portresi çizilen Laura, öldükten sonra da şaire ilham olmaya devam eder. Örneğin, Canzoniere, 'Laura Hayattayken' ve 'Laura Öldükten Sonra' başlıklarıyla iki kısımdan oluşur.9 Fakat her iki bölümde de Petrarca farklı biçimlerde de olsa Laura'yı nesneleștirmeye devam eder. Öyle ki, ölmeden önce sonelerde șehvet uyandıran bir nesne olarak göz alıcı güzelliğiyle beliren Laura öldükten sonra ise Sone 63, 90, 149 ve 156'da olduğu gibi insanüstü bir varlık, "ilahi bir figür" bir 'meleğe' dönüşür (1996: 214-452) ve Petrarca'yı Tanrı'ya ulaştıran yegâne güçtür. Bu bağlamda, varlığıyla da yokluğuyla da sone formunun kalıplarında cinsiyetçi

$7 \quad$ "Invaded by the World": Passion, Passivity, and the Object of Desire in Petrarch's "Rime sparse" adlı makalesinde Ross Knecht feminist edebi eleștiri kuramında kullanılan kadının "metalaștırılması” kavramı ile Petrarca'nın Laura'yı 'nesneleștirmesinin' birbirinden farklı olduğunu ve ayırt edilmesi gerektiğini vurgular. Knecht'e göre Petrarca sone dizisinde Laura'ya "obietto" olarak değindiğinde basitçe gördüğü ve ardından arzuladığı șeyden bahseder, dolayısıyla kelimenin 'maddesel vücut' ve 'meta' gibi modern çağrışımları [Petrarca'da] yoktur" (2011: 241).

8 Laura'nın tarihsel kimliği tam olarak bilinmemekle beraber Kont Hugues de Sade'nin eşi Laura de Nouves olabileceği ileri sürülmektedir. Bkz. Knecht, Ross (2011). "Invaded by the World": Passion, Passivity, and the Object of Desire in Petrarch's "Rime sparse". Comparative Literature, 63(3), 235-252. JSTOR, http://www.jstor.org/stable/41238524.

9 Bu başlıkların Petrarca'nın kendisinden ziyade eserini yayımlayanlar tarafından verilmiş olması oldukça muhtemeldir.

RumeliDE Dil ve Edebiyat Araştırmaları Dergisi $\quad$ RumeliDE Journal of Language and Literature Studies Osmanağa Mahallesi, Mürver Çiçeği Sokak, No:14/8 $\quad$ Osmanağa Mahallesi, Mürver Çiçeği Sokak, No:14/8 Kadıköy - İSTANBUL / TÜRKIYE 34714 Kadıköy - ISTANBUL / TURKEY 34714 e-posta: editor@rumelide.com $\quad$ e-mail: editor@rumelide.com, tel: +90 $5057958124,+90216773$ o 616 phone: +90 505 7958124, +90 216773 o 616 
stereotiplere sıkışıp kalmış kadın ataerkil Pertarca sone geleneğinde yüz yıllarca arzulanan bir 'nesne' olarak ele alınmaya devam etmiştir.

\section{Dişi Petrarca000 Elizabeth Barrett Browning ve "Sonnets from the Portuguese" (1845-46)}

Elizabeth Barrett Browning, kadıların erkek egemen Petrarca sonelerinin öznesi olabileceğini kanıtlayan ilk kadın şairlerden biridir. Öte yandan sağlık problemlerinden ${ }^{10}$ dolayı yaşamını bir odanın içinde herkesten izole geçiren Barrett Browning için geleneksel toplumun empoze ettiği toplumsal cinsiyet rollerine karşı çıkmak pek de kolay olmamıştır. Eşi Robert Browning'e duyduğu aşkı dile getirdiği kırk dört soneden oluşan "Sonnets from the Portuguese" adlı sone dizisini 1845-46 ylları arasında yazmasına rağmen ancak 1850 yılında yayımlar. Daha önce de bahsedildiği üzere, kadının aşk sonesinin öznesi olmasının pek mümkün olmadığı bir toplumda0 sone dizisinin otobiyografik ve öznel olması gerekçesiyle yayımlamak istemeyen Barrett Browning, eşinin ısrarları sonucunda sone dizisini yayımlamayı kabul eder. Fakat eseri anonim kılmak için yabancı dildeki sonelerin çevirisi gibi gösterir ve Portekizli şair Luis de Camoes'e duyduğu hayranlıktan dolayı sone dizisini "Sonnets from the Portuguese" yani "Portekiz Soneler" adı ile yayımlar (Stone \& Taylor, 2009: 205).

Tüm bunlar göz önünde bulundurulduğunda ve Barrett Browning'in Petrarca sonelerinin çevirilerini yaptığı da düşünüldüğünde, "Sonnets from the Portuguese"de Barrett Browning'in erkek egemen Petrarca sone geleneğini tüm kalıplarıyla özümsemesini, Petrarca'nın kullandığı sone formunu, vezni, uyağı ve hatta metaforik dili benimseyerek adeta dişi bir Petrarca dönüşmesini yadırgamak pek mümkün değildir. Örneğin, Sone 18'de "Bir adama saçımın bir buklesini bile vermem / Eğer o sevgili sen olmazsan"11 diyerek Petrarca'nın saray aşkı geleneğinden aldığı ad aktarmasını kendi aşk sonesine aktarır. Yine saray aşkı geleneğinden gelen 'hastalık' metaforunu sıklıkla kullanır. Saray aşkı geleneğinde "karasevdalı şairin tipik semptomları iç çekmek, bayılmak, beti benzi atmak ya da kızarmaktır" (Remoortel, 2006: 255), ve sonenin karasevdalı kadın konuşmacısı sone dizisi boyunca hastalıklıdır, elleri titrer, beti benzi atar, ağlamaktan gözleri kızarır, yanakları al al olur. Nitekim, Dorothy Mermin'in "The Female Poet and the Embarrased Reader: Elizabeth Barrett Browning's Sonnet from the Portuguese" adlı çalışmasında da dile getirdiği gibi sone dizisindeki aşık sevdiğine "Sevgili", "Birtanem" ve "Canım" gibi kelimelerle hitap etmesinden dolayı 'saray aşığından' ziyade kocasına seslenen bir 'Viktorya kadınını' andırmaktadır (1981: 358). Bu bakımdan Barrett Browning sone dizisi boyunca kadınlara yüklenen rolleri benimseyerek erkek kimliği ile yazdığı için çoğunlukla eleştirilir. Fakat Barrett Browning'e göre kadınların iyi bir şair olabilmesi için öncelikle erkek şairlerin kulvarlarında yarışıp, onların değer atfettiği şiirsel türlerde onları geçmesi gerekir (Byrd, 1987: 28). Dolayısıyla bu kulvarlardan biri olan, kuralları erkeklerin belirlediği Petrarca sone geleneğini benimseyerek kadınları duygusuz bir arzu 'nesnesi' konumundan duyguları, düşünceleri olan 'özne' konumuna taşıyı sonelerinin lirik öznesini kadın yapan Barrett Browning böylelikle ataerkil sone formunda erkek şairlere meydan okuyarak kadınların da iyi bir şair olabileceğini kanıtlama fırsatı bulur.

Ne var ki, toplumdaki cinsiyet ayrımcllı̆̆ ve kadınların ötekileştirilmesi ile ilgili eleştirilerini her fırsatta dile getiren Barrett Browning'in sone dizisinde toplumsal cinsiyet rollerini benimsemesi ve kadın özneyi itaatkâr ve değersiz göstermesi tezat oluşturmaktadır. Bu bakımdan, kadın haklarının savunucularından biri olan Mary Wolstonecraft'a hayranlığıyla da bilinen Barrett Browning' in sone dizisinde kadını aşağı bir

10 Barrett Browning yaşamı boyunca ciğerlerinden kaynaklı bazı fiziksel hastalıklarla ve ruhsal buhranlarla savaşmak zorunda kalmıştır. Öte yandan, bu durum Barrett Browning'in entelektüel bir şair olmasına büyük katkı sağlar çünkü bu süre zarfinda Barrett Browning çok az dışarı çıkar, nadir ziyaretçi kabul eder ve vaktinin çoğunu ise kitap, gazete ve dergi okuyarak geçirir. Deirde David'e göre, bu haliyle Barrett Browning “hayatını kütüphanede geçiren erkek bilginlerin dişi versiyonudur” (1987: 101).

${ }_{11} \quad$ Alice Chapman'a göre buklenin hediye olarak sevgiliye verilmesi genellikle saray çevresince kullanılan ve romantik ilişkinin cinsellikle tamamlanması anlamına gelen bir ad aktarmasıdır (2007: 106).

Adres $\mid$ Address

RumeliDE Dil ve Edebiyat Araştırmaları Dergisi $\quad$ RumeliDE Journal of Language and Literature Studies

Osmanağa Mahallesi, Mürver Çiçeği Sokak, No:14/8 $\quad$ Osmanağa Mahallesi, Mürver Çiçeği Sokak, No:14/8

Kadıköy - İSTANBUL / TÜRKIYE 34714 Kadıköy - ISTANBUL / TURKEY 34714

e-posta: editor@rumelide.com e-mail: editor@rumelide.com,

tel: +90 505 7958124, +90 2167730616 phone: +90 505 7958124, +90 2167730616 
From being 'object' to being 'subject': the rewriting of Petrarch's sonnet tradition from a female perspective in the sonnets of Elizabeth Barrett Browning and Christina Rossetti / S. Varal (pp. 193-203)

pozisyonda yansıtmasının tek sebebi kadının ikincil statüsünü kabul etmesi değil ancak ataerkil sone geleneğinin kalıpları içerisinde yazması olabilir. Başka bir deyişle, aşk sonesinin kadın öznesi Petrarca'nın yaptığı gibi sevdiğinin fiziksel güzelliğini, iffetini ve erdemini idealize etmesi ve onu bir arzu nesnesine dönüştürmesi gülünç olacağından ve Viktorya Dönemi İngiltere'sinde ahlaksızlık olarak algılanacağından ancak kendini yererek sevdiğini yüceltir. Örneğin Sone 16'da aşkının kendi değersizliğini azalttığını ileri sürerek “Değerimi arttırmak için aşkını daha da büyüteceğim” (2009: 215) derken Sone 32'de sevdiğini “iyi bir şarkıcı" kendini de "akordu bozuk viyola"ya benzetir (2009: 225) ve böyle bir adamın sevgisine layık olmadığını dile getirir. Fiziksel ve ruhsal yıpranmışlığını ve yorgunluğunu sıklıkla vurgular ve Sone 39'da ruhunun derinliklerini yani "Yllların yağmurlarıyla ağartarak soldurduğu maske[sinin] ardını” görecek gücü ve inceliği olduğu için sevdiğini över (2009: 228).

Öte yandan, kendi değersizliğini yalnızca fiziksel özelliklerine dayandırmayan kadın aşık sevdiğiyle arasındaki sınıf farkına dikkat çekerek değersizliğini toplumdaki aşağı pozisyonu ile daha da perçinler. Bu bağlamda, Sone 3, 8 ve 9'da sevdiğinin asilliğini ve soyluluğunu kendi değersizliği ve zavallılığıyla kıyaslar ve cömert sevgilisine verebileceği bir şey olmadığı için üzülür. Örneğin, Sone 9'da sevgilisine tuzlu gözyaşları ve nadir gülen dudaklardan başka bir hediye veremeyeceğini söyler, sevgili olmak için birbirlerine denk olmadıklarını şu sözlerle gözler önüne serer:

Benim verebildiklerimi verenler

Cömert olmayanlardan sayılmalı. Ne yazık!

Kirletmeyeceğim senin morunu benim tozumla

Ne nefesimle zehirleyeceğim Venedik-kadehini

Ne de vereceğim sevgimi ...bu haksızlık!

Sevgili, yalnızca seviyorum seni! boş veriyorum gerisini. (2009: 211)

Kendi değersizliğini sevdiğiyle arasındaki sosyal statü farkıyla da ortaya koyan kadın aşık Viktorya Dönemi'nde kadın erkek arasındaki maddi eşitsizliğe ve kadınların ekonomik durumuna bir nebze olsun ışık tutar. Kendini 'toz' olarak nitelendirerek toplumun alt tabakasından olduğunu ima ederken sevdiği için kraliyet ailesinin rengi olan "mor"u ve "Venedik bardağını" kullanarak onun aristokrat kesiminden olduğuna göndermede bulunur. Tüm bunlara rağmen onu sevdiğini bir kez daha söyleyerek, bu serzenişlerini unutmasını isteyerek soneyi sonlandırır. Nitekim, kendi fakirliği ve değersizliği karşısında sevdiğinin zenginliği ve soyluluğunu "mor" rengini kullanarak Sone 16'da tekrar vurgular:

Ve yine de üstesinden geldiğin için

Daha asil ve bir kral gibi olduğun için

Bitirebilirsin korkularımın hepsini

Ve örtebilirsin morunu üzerime ta ki kalbim

Yalnızken nasıl titrediğini bileceğin kadar

Yaklaşana dek kalbine. (2009: 215)

Kadın aşık sevdiğini çekincelerine ve korkularına galip gelen asil bir krala benzeterek bir yandan sevdiğini yüceltirken bir yandan da yalnızlık, melankoli ve korku içinde geçen hayatını gözler önüne serer. Sone dizisi boyunca sevdiğini tanımadan öncesini ve sonrasını kıyaslayarak sevdiğini düștüğü bu dünyadan onu kurtaran 'bir kurtarıcı' olarak yüceltir. Öyle ki, Sone 27'de "kurtarma öpücüğü" ile ona hayat veren sevdiğini bulduğu için artık "güvendedir", "güçlüdür" ve "mutludur" (2009: 222).

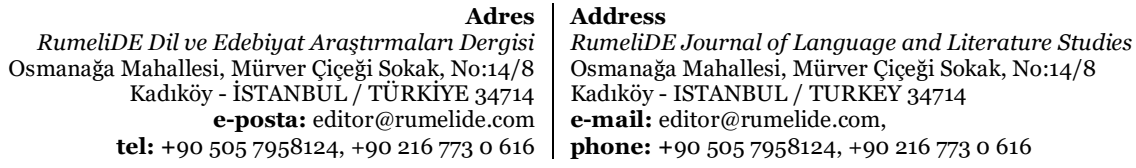


Tüm bunlara rağmen, Barrett Browning sone dizisinde arzu eden ve arzularını açıç̧a dile getiren bir kadın özne ortaya koyar. Kadın konuşmacı Sone 43'de "Seni nasıl severim? İzin ver anlatayım" (2009: 231) diyerek aşkını haykırmaktan çekinmez, ilişkide arzunun ve ihtirasın önemini vurgulayarak sevdiğiyle birlikte olmak için Sone 29'da itibarından ve düşüncelerinden bile vazgeçerek en mahrem duygularını açığa çıkarır (2009: 223). Kadının yalnızca gülüşüyle, bakışıyla var olduğu Petrarca'nın sonelerine göndermede bulunarak Sone 14'te "Sakın deme/ Onu gülüşü- bakışı -kibar konuşması için seviyorum diye" diyerek onu bu tarz geçici şeyler için değil yalnızca aşk için sevmesini ister çünkü sadece aşk sonsuza kadar kalır (2009: 214). Benzer şekilde kendini "zavallı, yorgun ve dalgın", "bitkin ve zayıf", "solgun yanakları", "kırık kalbinin yükünü taşıyamayan titrek bacakları" olan, duygusal ve fiziksel olarak kusurlu değersiz, önemsiz, depresif ve melankolik bir kadın olarak betimleyerek Petrarca sonelerinde cazibeleriyle ve güzellikleriyle nesneleştirilen kadınlara tamamen zıt bir portre çizer (Paul, 1989: 82). Bunların yanı sıra, bazı sonelerde yapısökümcü bir bakış açısıyla cinsiyet rollerini alaşağı eder. Örneğin, Sone 16'da kendini "savaşta mağlup olmuş bir askere" (2009: 215), Sone 31'de ise sevdiğini genellikle edebi eserlerde kadınları nitelendirmek için kullanılan "güvercine" (2009: 224) benzeterek kendine 'eril' sevdiğine 'dişil' özellikler atfeder ve cinsiyetçi stereotiplere karşı çıkar. Böylelikle, ataerkil Petrarca sone geleneğini yeniden yazarak normlarını yıkan Barrett Browning, kadınların yalnızca güzellikleriyle değil duygularıyla ve düşünceleriyle var olabileceklerini gösterir ve arzu nesnesi olarak sessizleștirilen kadınların iç dünyasına tercüman olur.

Nitekim tüm bunlar Barrett Browning'in Viktorya Dönemi'nde erkek kimliğiyle yazan bir "Dişi Petrarca" gibi algılanmasının ve sone dizisinin toplumsal cinsiyet rolleri çerçevesinde kocasına tamamen kendini adamış bir kadının aşk şiirleri olarak anılmasının önüne geçemez. Çağın bir diğer önemli kadın şairi olan Christina Rossetti de her ne kadar Barrett Browning'e hayranlığını dile getirerek onu "ulusun ve çağın en büyük kadın şairi" olarak nitelendirse de bu eleştirilere katılmadan edemez (Rossetti, 2008: 227). "Monna Innominata" adlı sone dizisine yazdığı önsözde Rossetti, Robert Browning ile evlenen Barrett Browning'in mutlu biten aşkın öznesi olarak Laura ve Beatrice gibi nesneleştirilen "donna innominata"ların- yani bilinmeyen, isimsiz kadınların- sesi olamayacağını, çünkü mutluluğun şiirlerini “duygudan” yoksun kıldığını ve sone geleneğinin ataerkil bakış açısını benimsemesine yol açtığını dile getirir. Nihayete eremeyen bir aşkın öznesi olarak nesneleștirilen isimsiz kadınların sesi olmayı amaç edinen Rossetti yazdığı sone dizisiyle erkek egemen Petrarca sone geleneğinin normlarını yıkan Viktorya Dönemi kadın şairlerinin başında gelir.

\section{Sessiz Kadınların Sesi: Christina Rossetti ve “Monna Innominata: A Sonnet of Sonnets” (1881)}

Christina Rossetti erkek egemen edebiyat sahnesinde yazdığı aşk soneleriyle Viktorya Dönemine damgasını vuran bir diğer kadın şairdir. Rossetti, özellikle 1881 yılında yayımladığı sone dizisi “Monna Innominata: A Sonnet of Sonnets" ile ataerkil Petrarca sone geleneğini yeniden yazarak kadınların birer arzu nesnesi olarak resmedilmesine karşı gelir. "Monna Innominata”ya yazdı̆̆ı önsöz ile ataerkil sone geleneğine başkaldırısını açıkça dile getiren Rossetti, Petrarca ve Dante'nin Laura ve Beatrice'i 'dişil güzelliğin ve cazibenin vücut bulmuş hali' olarak resmettikleri isimsiz, -yani kimliksiz, bireysellikten yoksun, karakteri olmayan "donne innominate'lerin"- sesi olsa durumun çok farklı olabileceğini şu sözlerle vurgular: "Böyle bir hanımefendi kendi adına konuşabilseydi, önümüzde beliren portre, daha az onurlu olsa bile, sadık bir arkadaşın çizdiğinden çok daha sempatik görünürdü bize" (Rossetti, 2008: 227). Bu bağlamda, Rossetti "meçhul kadın" anlamına gelen "Monna Innominata" ile kadınların kendi adına konuşup duygularını düşüncelerini ifade etmesini sağlayarak erkek sone yazarlarının yarattığı kadın portresini kadın bakış açısıyla tersyüz etmeyi amaçlar.

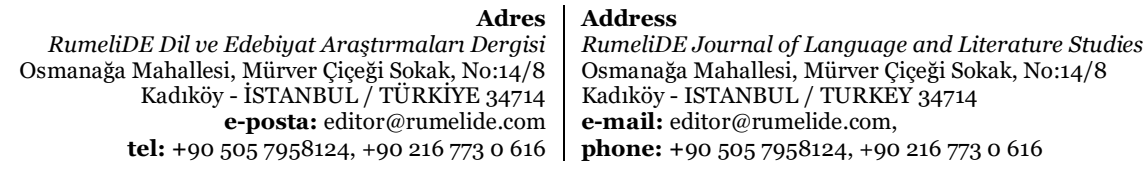


From being 'object' to being 'subject': the rewriting of Petrarch's sonnet tradition from a female perspective in the sonnets of Elizabeth Barrett Browning and Christina Rossetti / S. Varal (pp. 193-203)

"Sonelerin Sonesi" alt başlığıyla da bilinen "Monna Innominata" her biri ataerkil sone geleneğine gönderme yaptığı Petrarca ve Dante epigraflarıyla başlayan on dört soneden oluşan bir 'makro' sonedir. Sonenin 'oktav' bölümünü oluşturan ilk sekiz sonesi kadın öznenin aşkını optimistik bir şekilde gözler önüne sererken dokuzuncu sonedeki 'volta'dan sonraki son altı sone, yani 'sestet', bu dünyevi aşkı ilahi aşka dönüștürür ve din sevenlerin arasında üstesinden gelinemez bir 'engel' teşkil eder (Whitla, 1989: 89).12 Dindar olmasıyla bilinen ve dini farklılıklarından ötürü Charles Cayley ile evlenmekten vazgeçen Rossetti böylelikle sone dizisinde aşk sonelerindeki "saray aşkı" geleneğinden "mistisizm"e yönelir (Lysack, 1998: 402). Dolayısıyla Petrarca sone geleneğinde sevgiliye duyulan aşkın ve arzunun yerini ilahi aşk alır. Öyle ki, sevgiliye duyulan aşkın Tanrı'ya duyulan aşktan üstün tutulduğu Elizabett Barrett Browning'in sonelerinin aksine Rossetti'nin kaleminde ilahi bir yöne evrilen aşk sonesi, Tanrı, sevgili ve aşı üçgeninde -Sone 6'da da görüldüğü üzere- Tanrı'ya olan aşk baskın çıar. Bu çerçevede, sone dizisi gençlik ve güzelliğin geçici olduğunu vurgular; bu durumda, geriye sadece ilahi aşk kalır.

İlk üç sonede Petrarca sone geleneğine uygun olarak kadın aşık sevgilisine duyduğu aşkı bir 'saray aşı̆̆ı' edasıyla gözler önüne serer. Öte yandan Barrett Browning'in aksine, bu soneler geleneğe katı katıya bağlı kalmaz. İlk sone kadın konuşmacının sevgilisinin yokluğuna olan serzenişini yansıtır. Petrarca sonelerinde aşk nesnesinin yokluğu öznenin özlem ve aşk gibi duyguları daha yoğun yaşamasına ve sevgilinin farklı şekillerde yüceltilmesine yol açar. Sevgiliyi değerli kılan varlığından ziyade yokluğu ve ulaşılmazlığıdır aslında. Fakat, bu durum Rossetti'nin sone dizisindeki meçhul kadın öznenin sevdiğini olağan dişı benzetmelerle yüceltmesine yol açmaz; kadın özne sevdiğinin dış görünüşü hakkında hiç bilgi vermez, ona karşı nasıl tepki verdiğini neler hissettiğini de aktarmaz. Sadece aşkını görememesinden ancak öbür dünyada ya da rüyalarda buluşabileceklerinden bahseder.

Rossetti, Sone 2'de Petrarca sone geleneğinin sınırlarını daha da esnetir. Sonenin Petrarca'nın "Seni ilk gördüğüm zamanı tekrar hatırlıyorum" (Canzoniere, 20.3) ve Dante'nin "Arzuyu geri getiren saat çoktan gelmişti" (Purgatory, 8.1) epigrafları ile başlaması bu iki öncü şairin sonelerinde ilk tanışma anın ne denli önem arz ettiğini ortaya koyarken Rossetti'nin kadın öznesi sevdiği ile ilk karşılaştığı günü hatırlamaz:

Keşke o ilk günü anımsayabilsem

Benimle karşılaştığın ilk saati, ilk anı

Mevsim loşsa ya da ışıltıll,

Söyleyebileceğim ancak ya yazdır ya da kıștır; (2008: 228)

Laura ve Beatrice'i ilk gördükleri anı idealize eden Dante ve Petrarca'nın karasevdalı aşıklarının karşısında kadın öznenin böyle bir günü unutması bu durumun bir nevi parodisi olmakla kalmaz aynı zamanda görmezden gelinen kadın deneyiminin eleştirisi niteliğindedir. Başka bir ifadeyle, Rossetti, Laura ve Beatrice gibi “donne innominate"ler için ilk tanışma anın aynı önemi taşımayabileceğini gösterir.

Petrarca'nın sonelerinde beliren saray aşkı geleneğinin tam olarak yansıtıldığı tek sone olan Sone 3'de kadın aşığın rüyalarında sevdiğiyle buluştuğu için "yanakları al al olur", uyanınca ise sevdiği yanında olmadığı için "beti benzi atar", sevdiğinin gülüşü geceyi gündüze çevirir. Aşkını yalnızca mutlu rüyalarda nihayete erdirebilen kadın aşık "Mutlu rüyalarımda seni görebiliyorum ancak [...] /Eğer böyle uyumak, uyanmaktan daha tatlıysa, / Ölmek kesinlikle yaşamaktan daha tatlıdır” diyerek ölümü bile arzular (2008: 228). Bu

Rossetti'nin “Monna Innominata"nın bir sone dizisi olarak bütün halinde basılmasını istemesi ve bu konudaki ısrarını sıklıkla dile getirmesi sone dizisinin sevgiliye duyulan dünyevi aşkla başlayıp Tanrı'ya duyulan ilahi aşka yönelerek bir bütün olușturmasından kaynaklanması oldukça muhtemeldir. Diğer bir deyișle, Rossetti sone dizisinin bireysel soneler olarak değil de makro-sone olarak bastırarak eserin bütün olarak ortaya koyduğu "ilahi aşk" temasının göz ardı edilip eserin yalnızca sevgiliye yazılan bir aşk sonesi olarak algllanmasının önüne geçmiş olur.

$$
\text { Adres } \mid \text { Address }
$$

RumeliDE Dil ve Edebiyat Araştırmaları Dergisi $\quad$ RumeliDE Journal of Language and Literature Studies

Osmanağa Mahallesi, Mürver Ciiçeği Sokak, No:14/8 Osmanağa Mahallesi, Mürver Çiçeği Sokak, No:14/8

Kadıköy - İSTANBUL / TÜRKIYE 34714 Kadıköy - ISTANBUL / TURKEY 34714

e-posta: editor@rumelide.com $\quad$ e-mail: editor@rumelide.com,

tel: +90 505 7958124, +90 216773 o 616 phone: +90 505 7958124,+90 2167730616 
çerçevede, Rossetti geleneksel aşk sonesin imgelemini kullansa da sonede arzulanan uzaktaki kadın sevgilinin yerini erkek alır. Bunun yanı sıra, saray aşkı geleneğinde kara sevdalı aşığın önündeki en büyük engel sevgilinin başka birisiyle evli olmasıyken Rossetti "dini" bir bariyere dönüştürerek sone geleneğine bir kez daha alaşağı eder ve İncil'e yapılan atıflarla bu dini bariyer daha da gözler önüne serilir. Öncelikle Sone 5'de "O seni mükemmel kıldığı için mükemmelsin" diyerek sevdiğinin mükemmelliğinin Tanrı'nın eseri olduğunu vurgular (2008: 229). Sone 6'da benzer şekilde dini inanciyla sevdiğini bir arada tutmaya çabalar:

Oysa ben en çok Tanrı'yı severken, zannımca

Sevemeyeceğim asla seni gereğinden fazla;

O'nu daha çok seviyorum, bırak seni de seveyim

Evet aşk öyle bir şey ki, anladığım kadarıyla,

O'nu sevmezsem seni sevemem,

Seni sevmezsem O'nu sevemem. (2008: 230)

Dolayısıyla, dişil arzuları ile dini inancı arasında denge kurma çabasında olan kadın özne gelgitler yaşar çelişkili bir tutum sergiler. Makro-sone boyunca gözlemlenen bu durumu Linda Schofield şöyle açıklar: "Bireysel sonelerde, konuşmacının çelişen dürtülerinin çeșitli tezahürleri gözlemlenebilir. Fedakarlıklardan bahsedilir ama asla gerçek anlamda yapılmaz; arzular ifade edilir, ancak asla gerçekleşmez. Cennette kurtarıı bir birleşmeyle ilgili ipuçları asla koşulsuz iddialar değildir" (1997: 41). Özellikle Sone 7'de, isimsiz kadın özne "mutlu aşk diyarında" 'eşitliği' arayacak ve bunu cesurca dile getirecek kadar güçlü olsa da "kalbinin sözleri kadar cesur olmadığını" (2008: 231) söyleyerek açıkça bir çelişki ortaya koyar. Kadının her alanda görmezden gelinmesinden dolayı kendinden önce örnek alabileceği bir kadın geleneği bulamayan kadın özne ancak İncil'e yönelerek cesaretinden ve gücünden ilham alabileceği bir kadın bulur:

“Ölürsem öleyim” -dedi Ester:

[...]

İpeksi bir saç örgüsüyle tuzağa düşürdü kocasını,

Bilgeliğiyle yendi onu,

Ve ayakta durması için inşa etti halkının evini: -

Eğer hayatımı bu kadar elime alabilsem,

Ve aşkım için Aşk'a duamı sunarım,

Ki aşk hatırı için Aşk tarafından kabul edilsin! (2008: 231)

Yahudi kraliçe Esther'in dişil güzelliğini kullanarak kocasını baştan çıkarıp Yahudi halkını ölümden kurtarmasını ele alan sonede kadın özne, "Güvercinler kadar zararsız ve bir yılan kadar kurnaz" (2008: 231) olarak betimlenen Esther'i över. Öyle ki, klasik epik geleneğinde erkeklere atfedilen kahramanlık özelliklerini sergileyen ve ölümü göze alan Esther, Viktorya döneminde ahlaksızlık olarak görülen kadın cinselliğini ve cazibesini ahlaki bir amaç için kullanır ve halkını kurtarır. Bu alışılmadık gönderme ile Rossetti hem Viktorya Dönemi'nin katı cinsiyetçiliğine hem de Petrarca sonelerinde kadının edilgenleștirilmesine baş kaldırır. Sone 8 aynı zamanda kadın öznenin aşkının nihayete ermesini beklediği son sonedir.

Sone 9, volta, kadın özne aşkına dair umutlarını öbür dünyaya bırakır. Bu bağlamda, son beş sone isimsiz kadının sevgilisinden vazgeçme ve mağlubiyet psikolojisini ortaya koyar (Triggs, 1989: 10). Kadın

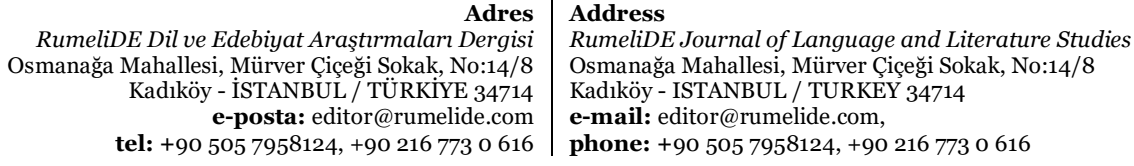


From being 'object' to being 'subject': the rewriting of Petrarch's sonnet tradition from a female perspective in the sonnets of Elizabeth Barrett Browning and Christina Rossetti / S. Varal (pp. 193-203)

konuşmacı artık dünyevi aşkta mutluluğu aramaktan vazgeçer ve Sone 10'da her şeyin fani ve geçici olduğuna vurgu yaparak mutluluğu öbür dünyada arar:

Hadi uyuyalım sevgili dostum, huzur içinde:

Yaș ve keder sona erer kısa bir süre içinde;

Kısa bir süre içinde hayat yeniden doğar ve önemsizleştirir

Kayıpları, parçalanmaları, ölümü ve hepsi aşktır. (2008: 232)

Sessiz kadınların sessi olan sone dizisi nitekim ironik bir şekilde sessizlikle biter. Fakat "Monna Innominata"nın önsözünde de belirtilen yazılış amacı göz önünde bulundurulduğunda bu sessiz sonu Petrarca sone geleneğinde sessizleștirlen kadınların 'sessiz çı̆̆lıkları' olarak yorumlamak yanlış olmayacaktır.

\section{Sonuç}

Sonuç olarak, Elizabeth Barrett Browning ve Christina Rossetti sone dizileriyle kadını özneleştirerek iç dünyalarını yansıtmış, onlara bir kimlik ve bireysellik bahşederek sadece güzellikten ibaret olmadıklarını kanıtlamıştır. Böylelikle yüzyıllardır kadını duygusuz bir arzu nesnesine dönüştüren erkek egemen Petrarca sone geleneğine karşı çıkmıştır. Barrett Browning'in "Sonnets from the Portuguese" eserinde belirli sınırlar içerisinde kalan bu karşı çıkış, Petrarca'nın kadın nesnelerine zıt bir portre çizilerek, melankolik, depresif ve yıpranmış kadın öznenin sonede duyguları, düşünceleri ve çekinceleriyle var olmasıyla ortaya konur. Öte yandan, Christina Rossetti sone dizisi "Monna Innominata"da dişil arzuları ile dini inancı arasında karmaşık duygularını dile getiren bir kadın özne resmederek erkek egemen sone geleneğinden ayrilışı daha bariz bir şekilde ortaya koyar. Nitekim, Viktorya Dönemi'nin iki önemli kadın şairinden birinin aşk sonelerini kocasına yazması ötekinin ise dişil arzularını dini inancıyla perdelemesi dönemin cinsiyetçi stereotipleriyle örtüşüyor gibi görünse de Browning ve Rossetti kadını ataerkil Petrarca sone geleneğinin edilgen arzu nesnesi olmaktan kurtarıp 'arzulayan özneye' dönüştürür. Böylelikle, iki kadın şair de sessiz kadınların sesi olmayı başarmakla kalmaz kadınların da erkekler kadar iyi aşk sonesi yazabileceklerini gözler önüne serer.

\section{Kaynakça}

Browning, B. E. (2009). "Sonnets from the Portuguese". Elizabeth Barrett Browning: Selected Poems. Ed. Stone, M. \& Taylor, B. Canada: Broadview Editions. s.204-232.

Browning, B. E. (1872). Aurora Leigh and Other Poems. New York: James Miller Publisher.

Byrd, D. (1987). Combating an Alien Tyranny: Elizabeth Barrett Browning's Evolution as a Feminist Poet. Browning Institute Studies, 15, 23-41. JSTOR, http://www.jstor.org/stable/25057802.

Chapman, A. (2007). "Sonnet and Sonnet Sequence". A Companion to Victorian Poetry. Ed. Richard Cranin, Alison Chapman and Antony H. Harrison. Oxford: Blackwell Publishing.

Deirdre, D. (1987). Intellectual Women and Victorian Patriarchy: Harriet Martineau, Elizabeth Barrett Browning, George Eliot. London: MacMillan Press.

Distiller, N. (2008). Desire and Gender in the Sonnet Tradition. London: Palgrave Macmillan.

Garrett, M. (ed.) (2000). Elizabeth Barrett Browning and Robert Browning: Interviews and recollections. London: Macmillan.

Gilbert, S. \& Susan G. (1996). “The Aesthetics of Renunciation” Victorian Women Poets. Ed. Tess Cosslet. London and New York: Longman.

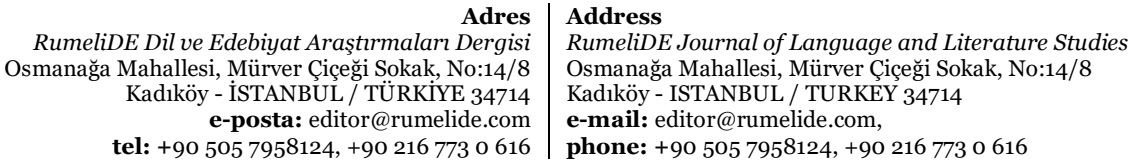

RumeliDE Dil ve Edebiyat Araşttrmaları Dergisi tel: +90 505 7958124, +90 2167730616 
Knecht, R. (2011). "Invaded by the World": Passion, Passivity, and the Object of Desire in Petrarch's "Rime sparse". Comparative Literature, 63(3), 235-252. JSTOR, http://www.jstor.org/stable/41238524.

Lysack, K. (1998). The Economics of Ecstasy in Christina Rossetti's "Monna Innominata". Victorian Poetry, 36(4), 399-416. JSTOR, http://www.jstor.org/stable/40002233

Moore, B. M. (1945). Desiring Voices Women Sonneteers and Petrarchism. Carbondale ve Edwardsville: Southern Illinois University Press.

Paul, S. (1989). Strategic Self-Centering and the Female Narrator: Elizabeth Barrett Browning's "Sonnets from the Portuguese". Browning Institute Studies, 17, 75-91. JSTOR, http://www.jstor.org/stable/25057847.

Petrarca, F. \& Musa, M. (1996). Petrarch: The Canzoniere, or Rerum vulgarium fragmenta. Bloomington, Ind: Indiana University Press.

Remoortel, V. M. (Fall 2006). “(Re)gendering Petrarch: Elizabeth Barrett Browning's 'Sonnet from the Portuguese". Tulse Studies in Women Literature. 25(2), 247-266.

Rossetti, C. (2008). Poetry and Prose. Ed. Simon Humphries. Oxford ve NewYork: Oxford University Press.

Scofield, L. (Spring 1997). “Displaced and Absent Texts as Contexts for Christina Rossetti's Monna Innominata". Journal of Pre-Raphalite Studies. s.38-52.

Spiller, M. R. G. (1992). The Development of the Sonnet An Introduction. London and New York: Routledge.

Smarr, J. L. (2001). "Substituting for Laura: Objects of Desire for Renaissance Women Poets”, Comparative Literature Studies, 38(1), 1-30. JSTOR, http://www.jstor.org/stable/40247277.

Stone, M. \& Taylor, B. (2009). Elizabeth Barrett Browning: Selected Poems. Canada: Broadview Editions. s.204.

Trapp, J. (2001). Petrarch's Laura: The Portraiture of an Imaginary Beloved. Journal of the Warburg and Courtauld Institutes, 64, 55-192. doi:10.2307/751561.

Triggs, J. A. (1989). Christina Rossetti's Sonnet of Sonnets: Monna Innominata. s. 15. https://doi.org/10.7282/T3J969HW

Whitla, W. (1987). Questioning the Convention: Christina Rossetti's Sonnet Sequence "Manna Innominata". In Kent D. (Ed.), The Achievement of Christina Rossetti (s. 82-131). Ithaca; London: Cornell University Press. JSTOR, http://www.jstor.org/stable/10.7591/j.ctvr7f9vz.8.

Adres
RumeliDE Dil ve Edebiyat Araştırmaları Dergisi Osmanağa Mahallesi, Mürver Çiçeği Sokak, No:14/8 Kadıköy - İSTANBUL / TÜRKIYE 34714 e-posta: editor@rumelide.com tel: +90 $5057958124,+902167730616$
Address

RumeliDE Journal of Language and Literature Studies Osmanağa Mahallesi, Mürver Çiçeği Sokak, No:14/8

Kadıköy - ISTANBUL / TURKEY 34714

e-mail: editor@rumelide.com

phone: +90 $5057958124,+902167730616$ 